\section{Long-term Yield and Harvest Time Fruit Quality Attributes in Various Fuji Apple Strains}

\author{
Esmaeil Fallahi ${ }^{1,5}$, Bahar Fallahi ${ }^{2}$, and Bahman Shafii ${ }^{3}$ \\ University of Idaho, Parma Research and Extension Center, $29603 \mathrm{U}$ \\ of I Lane, Parma, ID 83660
}

Zabihollah Zamani ${ }^{4}$
Department of Horticultural Science, University of Tehran, Karaj, Iran

Additional index words. cultivar selection, fruit color, Malus domestica, starch index

\begin{abstract}
Fuji' apple (Malus $\times$ domestica Borkh) has gained popularity in the past decades, but poor color of this apple mandates introduction of new strains. To pursue this objective, long-term effects of five 'Fuji' apple strains, consisting of 'Autumn Rose', 'Desert Rose', 'Myra', 'September Wonder', and 'Top Export' on RN 29 rootstock on fruit yield (in 7 years) and harvest time quality attributes (in 6 years) under climate conditions of southwest Idaho were studied during 2004-10. Fruit of 'September Wonder Fuji' trees were larger than those of other strains in 5 of 6 years. The type or pattern of peel color among the "low-coloring" and "high-coloring" strains varied widely. Fruits of 'Autumn Rose Fuji', 'Myra Fuji', and 'Top Export Fuji' always had less but 'September Wonder Fuji' and 'Desert Rose Fuji' had more red color. Fruit of 'September Wonder Fuji' had lower firmness but higher starch degradation pattern (SDP) than those of other strains every year as a result of the earlier maturity of this strain. Fruit of 'Top Export Fuji' had the lowest SDP among all strains. Fruit of 'Autumn Rose Fuji' tended to have lower soluble solids concentration in 3 of 6 years of this study. Considering all yield and quality attributes at harvest, 'September Wonder' was a great choice for an earlymaturing and 'Desert Rose' was suitable for a late-maturing 'Fuji' strain. 'Myra Fuji' was particularly desirable for its attractive pink color that resembles bagged 'Fuji' without the expensive cost of labor associated with bagging.
\end{abstract}

Merging new orchard designs with an efficient rootstock and high-coloring strain of an apple cultivar can result in production of higher yield with better fruit quality (Fallahi et al., 2011; Marini et al., 2008; Veberic et al., 2007). Consumer acceptance is determined by fruit color, size, eating quality, and texture (Crassweller and Hollender, 1989; Donati et al., 2003; Fisher and Ketchie, 1989; MacFie, 1995; Salveit, 1983). Nevertheless, poor color can drastically reduce the value of redpeeled apples even if they have acceptable fruit size (Baugher et al., 1990; Crassweller and Hollender, 1989; Iglesias and Alegre,

Received for publication 31 Dec. 2013. Accepted for publication 22 Jan. 2014.

We thank the Idaho Apple Commission, International Fruit Tree Association, and the Idaho Agricultural Experiment Station for their financial support of this project. We are also thankful to the Columbia Basin, Van Well, and $\mathrm{C} \& \mathrm{O}$ Nurseries in Washington State for providing the experimental trees and to Mr. Richard L. Bronson, Pipeco, and Fruitland, Idaho, for his invaluable contribution and assistance in designing the irrigation layout and providing the irrigation materials for this project.

${ }^{1}$ Professor and Director of Pomology.

${ }^{2}$ Scientific Aide in Pomology.

${ }^{3}$ Professor and Director of Statistical Program.

${ }^{4}$ Professor of Pomology.

${ }^{5}$ To whom reprint requests should be addressed; e-mailefallahi@uidaho.edu.
2006). Apple fruit color best in climates with preharvest period (Blankenship, 1987; Faragher, 1993; Westwood, 1993). Formation of red color in apple is also influenced by light (Arakawa, 1991; Saure, 1990), cultivar (Curry, 1997; Dickinson and White, 1986; Iglesias et al., 1999), strain (Fallahi et al., 2011; Greene and Autio, 1993), fruit bagging (Fallahi et al., 2001), evaporative cooling (Williams, 1993), and the use of reflective film to increase the intensity of light into the tree canopy (Ju et al., 1999). However, the high cost of many of these practices mandates planting high-coloring strains. Delaying harvest time can also improve color but this practice, in addition to the increased risk of freeze injury, can lead to higher respiration and endogenous ethylene production, lower firmness, and shorter storage life, particularly when trees are supplied with excess nitrogen (Fallahi et al., 1985).

Most of today's red-peeled cultivars are developed by apple breeding programs (Sansavini et al., 2005), but the majority of highly colored strains are identified based on visual and/or physiological changes that occur on a limb of the original cultivar tree (limb mutations) such as 'Gala', 'Delicious', or 'Fuji'. These mutants could show some reversions as a result of a lack of stability (Lacey and Campbell, 1987).

Differences in 'Fuji' strain quality attributes have been reported in Japan (Komatsu, clear bright days and cool nights during the
1998), Tasmania (Brown et al., 1998), and Spain (Iglesias et al., 2012). In each of these reports, a different set of strains has been compared for their quality attributes. Komatsu (1998) reported that color of different sports of 'Fuji' varied, depending on the location where they were grown and the year when they were observed. Some clones did well in cold but not hot climate areas and vice versa. Based on that report, the pattern of peel color (stripe or blush) was not always stable. Also, some striped strains reverted back to produce poorcolored apples like standard 'Fuji'. The striped-type sports showed more tendencies to develop red color in sectors than did the solid-type sports. Poor eating quality was detected in some red sports, more often in solid type than in stripe type. However, some striped-type clones were comparable with standard 'Fuji' (Komatsu, 1998). Iglesias et al. (2012) measured fruit anthocyanin content and visual color of different strains and reported that the most colored strain was 'Zhen Aztec Fuji' (blushed) followed by '6629 Fuji' (also blushed), 'Kiku 8 Fuji', and 'Rubin Fuji' (both striped). Differences in various quality attributes among 'Fuji' strains remained proportionally the same across different harvest times (Iglesias et al., 2012). Comparing four strains of 'Fuji' apples in Tasmania, 'Naga Fu 2 Fuji' produced the largest fruit with best red color but least firmness (Brown et al., 1998). In that study, Akafu strains maintained higher fruit firmness than Naga Fu strains. 'Naga Fu 1 Fuji' had lower soluble solids concentration (SSC) when compared with the other strains, whereas the 'Aki Fu 1 Fuji' fruit had a lower area of red peel. Veberic et al. (2007) compared fruit quality attributes of 'Kiku 7 Fuji', 'Kiku 8 Fuji', 'Naga-fu 6 Fuji', and 'Standard Fuji' over two seasons. In their study, 'Kiku 8 Fuji' fruit had the best red color and accumulated the largest amount of reducing sugars with the lowest quantity of phenols in both years and recommended this strain for planting in the areas with high variations in daily and nightly temperatures.

Although the Pacific Northwest, particularly Idaho, is a major area for production of 'Fuji', there have not been any comparative studies among different strains of 'Fuji' in the region. Thus, the objective of this long-term experiment was to study the yield and harvest time fruit quality differences among 'Fuji' strains in southwest Idaho, which has similar climate conditions as those of the Intermountain West region of the United States and many other regions worldwide.

\section{Materials and Methods}

Orchard establishment. The experimental orchard was established at the University of Idaho Parma Research and Extension Center in spring and early summer of 2002. The experimental site was located at latitude $43.8^{\circ}$ north, longitude $116.9^{\circ}$ west, and $673 \mathrm{~m}$ elevation above sea level with an annual precipitation of $\approx 297 \mathrm{~mm}$ and a sandy loam soil of $\mathrm{pH} \approx 7.3$. Crested wheatgrass 
[Agropyron cristatum (L.) Gaertn.], which is a drought-tolerant grass, was planted between the herbicide strips as the orchard floor cover in all treatments. Cultural practices other than the use of this set of strains were similar to those recommended for commercial orchards in the Pacific Northwest (Washington State University Tree Fruit Research and Extension Center, 2014).

'Autumn Rose Fuji', 'Desert Rose Fuji', 'Myra Fuji', 'September Wonder Fuji' (formerly named 'Jubilee Fuji'), and 'Top Export' strains, all on RN 29 rootstock, were planted at $1.52 \mathrm{~m} \times 4.27-\mathrm{m}$ spacing with an east-west row orientation. These strains are among the most commonly available 'Fuji' trees in the fruit industry in the United States and were thus used for comparison in this study. The trees were obtained from Columbia Basin Nursery, Quincy, WA; Van Wells Nursery, Wenatchee, WA; and C \& O Nursery, Wenatchee, WA. 'Snow Drift' crab apple (Malus $\times$ 'Snowdrift') on Bud 9 rootstock (C \& O Nursery) was planted in each row as a pollenizer between every 10 'Fuji' trees, because this arrangement ensures sufficient pollination to the actual trees (Westwood, 1993).

Trees were trained into a vertical axis system (Westwood, 1993) during the dormant season in early March every year. Tree central leaders were maintained at $\approx 3.7 \mathrm{~m}$ height. Trees in all treatments were blossomthinned at $\approx 80 \%$ bloom with $5 \%$ lime sulfur followed by one or two applications of postbloom thinners. The first post-bloom thinner (when applied, depending on the cropload) was a mixture of carbaryl ( $44.1 \%$ by weight a.i.; Sevin XLR; 1-naphthyl N-methylcarbamate; Bayer Crop Science, Research Triangle Park, $\mathrm{NC}$ ) at a rate of $0.156 \%$ to $0.187 \%$ of formulation and ethephon $\{21.7 \%$ a.i.; Ethrel [(2-chloroethyl) phosphonic acid]; Bayer Crop Science $\}$ at a rate of 0.125 to 0.156 of formulation was applied at petal fall. The second post-bloom thinner (when applied, depending on the cropload) was carbaryl at $0.125 \%$ to $0.156 \%$ formulation that was applied when fruitlet diameter was $\approx 7 \mathrm{~mm}$. Fruits were subsequently hand-thinned when they were $\approx 12$ to $18 \mathrm{~mm}$ in diameter (approximately mid-June) to maintain a space of at least 12.5 to $15 \mathrm{~cm}$ between fruits. Kaolin ( $95 \%$ a.i.; Surround; Englehard, Iselin, NJ) was sprayed for sunburn protection at a rate of $56.8 \mathrm{~kg} \cdot \mathrm{ha}^{-1}$ in early July followed by three 1-week interval applications, each at 28.4 $\mathrm{kg} \cdot \mathrm{ha}^{-1}$ every year.

Fruit yield and quality attributes. Thirtyfive fruits were randomly sampled from each tree for quality analysis and the total yield per tree was recorded as the total weight of all fruits at harvest time every year. Average weight of these 35 fruit was calculated. Twenty of these fruit were used for evaluation of quality attributes at harvest and 15 were kept in perforated plastics bags and stored in a regular storage at $0{ }^{\circ} \mathrm{C}$ and $90 \%$ relative humidity for 5 months. For quality evaluation, we harvested all strains together only at the traditional commercial harvest date, which was between 17 Oct. and 27 Oct. in the region. Although fruit in some strains were more mature at this harvest date, it was a harvest reference point to evaluate relative differences among strains in that "one point of time." The commercial maturity date was determined by a field visual inspection of the fruit peel and flesh color, taste, and sweetness. For fruit quality assessment at harvest, peel color was visually rated on a scale of 1 to 5 with $1=20 \%$ of peel surface covered with red color in either strip or blush pattern progressively to $5=100 \%$ of peel surface covered with red color. Thus, a color ranking of 3.5 corresponds with $\approx 70 \%$ of red color. We did not measure the intensity of fruit red color, although we took a note of the color intensity and pattern.

At harvest, each individual fruit was gently wiped with a damp cloth and the percentage of fruit with visible russet, minor cracks, bitter pit, and sunburn on the fruit peel was calculated as: (number of fruits with the disorder/total number of sampled fruit) $\times 100$. Cracks in this study are referred to minor fissures on the peel. We did not have any case of fruit splitting.

SSC was measured using a temperaturecompensated refractometer (Atago N1, Tokyo, Japan) and fruit firmness was measured, using an 11-mm probe, with a Fruit Texture Analyzer (Guss; Strand, Western Cape, South Africa) and firmness values were reported in Newtons $(\mathrm{N})$. Fruit were then cut equatorially in halves and percentage of fruit with watercore was determined as: (number of fruits with the watercore/total number of sampled fruit) $\times 100$. SDP of equatorial halves of each fruit at harvest was recorded by comparison with the SDP standard chart developed for 'Fuji' apples by Bartram et al. (1993). After storage, SSC, firmness, and percentages of disorders were measured. However, in this report, only results of quality attributes at harvest are reported.

Table 1. Effect of 'Fuji' apple strains on yield per tree in 7 years.

\begin{tabular}{lcccccccc}
\hline & \multicolumn{7}{c}{ Yield (kg/tree) } \\
\cline { 2 - 8 } Strain & 2004 & 2005 & 2006 & 2007 & 2008 & 2009 & 2010 & Cumulative \\
\hline Autumn Rose & $8.0 \mathrm{a}^{\mathrm{z}}$ & $18.9 \mathrm{a}$ & $17.3 \mathrm{a}$ & $13.1 \mathrm{a}$ & $9.8 \mathrm{~b}$ & $26.1 \mathrm{a}$ & $15.1 \mathrm{a}$ & $97.4 \mathrm{a}$ \\
Desert Rose & $7.4 \mathrm{a}$ & $13.3 \mathrm{ab}$ & $19.2 \mathrm{a}$ & $6.8 \mathrm{a}$ & $29.8 \mathrm{a}$ & $21.7 \mathrm{a}$ & $30.0 \mathrm{a}$ & $114.6 \mathrm{a}$ \\
Myra & $11.0 \mathrm{a}$ & $17.6 \mathrm{ab}$ & $16.0 \mathrm{a}$ & $17.0 \mathrm{a}$ & $26.1 \mathrm{ab}$ & $29.4 \mathrm{a}$ & $26.7 \mathrm{a}$ & $133.4 \mathrm{a}$ \\
S. Wonder & $7.5 \mathrm{a}$ & $4.6 \mathrm{c}$ & $11.2 \mathrm{~b}$ & $10.7 \mathrm{a}$ & $32.7 \mathrm{a}$ & $25.8 \mathrm{a}$ & $27.1 \mathrm{a}$ & $119.7 \mathrm{a}$ \\
Top Export & $8.4 \mathrm{a}$ & $12.0 \mathrm{~b}$ & $16.3 \mathrm{ab}$ & $11.4 \mathrm{a}$ & $21.1 \mathrm{ab}$ & $20.7 \mathrm{a}$ & $20.9 \mathrm{a}$ & $109.2 \mathrm{a}$ \\
\hline
\end{tabular}

${ }^{2}$ Mean separation within columns by Fisher's protected least significant difference at $P \leq 0.05$. For each strain, every value within a year represents an average of eight replications.

S. Wonder $=$ September Wonder.

Table 2. Effect of 'Fuji' apple strains on fruit weight in 6 years.

\begin{tabular}{llllllll}
\hline & \multicolumn{7}{c}{ Fruit wt $(\mathrm{g})$} \\
\cline { 2 - 7 } Strain & \multicolumn{1}{c}{2004} & \multicolumn{1}{c}{2005} & 2006 & 2007 & 2009 & 2010 & Avg 6 years \\
\hline Autumn Rose & $299.1 \mathrm{ab}^{\mathrm{z}}$ & $297.3 \mathrm{a}$ & $311.6 \mathrm{a}$ & $322.7 \mathrm{a}$ & $296.2 \mathrm{~b}$ & $275.9 \mathrm{a}$ & $299.8 \mathrm{ab}$ \\
Desert Rose & $289.0 \mathrm{~b}$ & $286.4 \mathrm{ab}$ & $318.4 \mathrm{a}$ & $273.0 \mathrm{~b}$ & $308.8 \mathrm{ab}$ & $283.5 \mathrm{a}$ & $291.1 \mathrm{~b}$ \\
Myra & $304.1 \mathrm{ab}$ & $279.4 \mathrm{ab}$ & $314.5 \mathrm{a}$ & $335.3 \mathrm{a}$ & $299.0 \mathrm{ab}$ & $271.8 \mathrm{ab}$ & $302.0 \mathrm{ab}$ \\
S. Wonder & $331.7 \mathrm{a}$ & $268.9 \mathrm{~b}$ & $334.2 \mathrm{a}$ & $338.8 \mathrm{a}$ & $326.7 \mathrm{a}$ & $290.4 \mathrm{a}$ & $314.1 \mathrm{a}$ \\
Top Export & $283.5 \mathrm{~b}$ & $291.8 \mathrm{ab}$ & $329.8 \mathrm{a}$ & $336.2 \mathrm{a}$ & $317.4 \mathrm{ab}$ & $250.7 \mathrm{~b}$ & $301.6 \mathrm{ab}$ \\
\hline
\end{tabular}

${ }^{\mathrm{z}}$ Mean separation within columns by Fisher's protected least significant difference at $P \leq 0.05$. For each strain, every value within a year represents an average eight replications.

$\mathrm{S}$. Wonder $=$ September Wonder. 
were not excessive to create a negative relationship between yield and fruit size. General fruit weight and yield relations in this study were in agreement with a comprehensive study on cropload adjustment reported from Japan by Koike and Ono (2014). Thus, differences among treatments for yield and fruit size are true strain rather than cropload effect.

Significant differences in fruit color were found among different strains of 'Fuji' (Table 3). In general, fruits of 'Autumn Rose Fuji', 'Myra Fuji', and 'Top Export Fuji' always had less but 'September Wonder Fuji' and 'Desert Rose Fuji' had more red color than other strains during each year and over 6 years of this study (Table 3). The type or pattern of peel color among the "low-coloring" and "high-coloring" strains varied widely. For example, 'September Wonder Fuji' seemed to mature $\approx 2$ weeks before other strains and had reddish blush and very attractive color. Fruit in 'Desert Rose Fuji' had evenly distributed red blush coloration on the peel, even in the shaded areas of the tree. Among strains tested here, 'Desert Rose Fuji' had the best color among late-season 'Fuji' strains. 'Myra Fuji' fruit peel had a uniform light red (almost pink) color covering the entire peel, resembling bagged 'Fuji', and the pink color was overlaid with slightly darker pinkish red stripes, giving an attractive and marketable appearance to the fruit. 'Top Export' had deep red stripes with wider strips of green-beige color in between. In this study, any peel color ranking less than 3.5 ( $70 \%$ red), when the background color was greenish or "muddy red," was considered less acceptable for the market (E. Fallahi, personal experience). The peel of 'Autumn Rose Fuji' fruit had a 6-year average color ranking of $3.2(\approx 64 \%$ red) (Table 3$)$ with poor red stripes and blush (mixed), and under high nitrogen conditions, the color was even less acceptable for the market (data not shown).

'September Wonder Fuji' had significantly lower fruit firmness than all other strains every year during 6 years of this study (Table 4 ) as a result of the earlier maturity of this strain.

'Autumn Rose Fuji' tended to have lower SSC in 3 of 6 years in this study (Table 5). However, averaging values over 6 years did not show any difference in SSC among strains. 'September Wonder Fuji' and 'Myra Fuji' had higher, whereas 'Autumn Rose Fuji' and 'Top Export Fuji' had lower SDP (Table 6), which could have contributed to the longer storage life of 'Top Export Fuji' (data not shown).

Fruit of 'Top Export' often had lower russet than those of other strains, although differences were not always significant (data not shown). Strains did not differ in the percentage of fruit sunburn or bitter pit in any year (data not shown). Percentages of fruit with watercore varied greatly from year to year and from strain to strain. However, 'Myra Fuji' tended to have (numerically or significantly) higher watercore in 4 of 6 years in this study (Table 7). 'Fuji' fruit with watercore is preferred in some apple markets, although watercore incidence is considered as a negative fruit quality attribute in other apple cultivars (E. Fallahi, personal knowledge). The incidence of fruit cracks was low in all strains; however, fruit of 'September Wonder' had a higher 6-year average surface crack (Table 7). These cracks perhaps were

not noticeable if fruit were harvested earlier than other strains.

Considering all yield and quality attributes at harvest, 'September Wonder' was a good choice for an early strain. Fruit yield, weight, and color in this strain were satisfactory. Lower firmness and higher SDP, watercore, and surface cracking of fruit in this strain could be improved by harvesting fruit at an

Table 3. Effect of 'Fuji' apple strains on fruit peel color at harvest in 6 years.

\begin{tabular}{lccccccc}
\hline & \multicolumn{7}{c}{ Fruit peel color $(1-5)^{\mathrm{z}}$} \\
\cline { 2 - 7 } Strain & 2004 & 2005 & 2006 & 2007 & 2009 & 2010 & Avg 6 years \\
\hline Autumn Rose & $2.8 \mathrm{c}^{\mathrm{y}}$ & $3.5 \mathrm{~b}$ & $3.0 \mathrm{bc}$ & $3.8 \mathrm{ab}$ & $3.6 \mathrm{~b}$ & $3.1 \mathrm{~b}$ & $3.2 \mathrm{c}$ \\
Desert Rose & $3.7 \mathrm{~b}$ & $4.4 \mathrm{a}$ & $3.7 \mathrm{ab}$ & $3.8 \mathrm{ab}$ & $4.5 \mathrm{a}$ & $4.2 \mathrm{a}$ & $4.0 \mathrm{~b}$ \\
Myra & $3.1 \mathrm{c}$ & $3.7 \mathrm{~b}$ & $2.8 \mathrm{c}$ & $3.4 \mathrm{~b}$ & $3.8 \mathrm{~b}$ & $3.0 \mathrm{~b}$ & $3.3 \mathrm{c}$ \\
September Wonder & $4.6 \mathrm{a}$ & $4.5 \mathrm{a}$ & $4.5 \mathrm{a}$ & $4.6 \mathrm{a}$ & $4.7 \mathrm{a}$ & $4.5 \mathrm{a}$ & $4.6 \mathrm{a}$ \\
Top Export & $2.6 \mathrm{c}$ & $3.4 \mathrm{~b}$ & $2.5 \mathrm{c}$ & $2.8 \mathrm{~b}$ & $3.6 \mathrm{~b}$ & $2.9 \mathrm{~b}$ & $3.0 \mathrm{c}$ \\
\hline
\end{tabular}

${ }^{\mathrm{z}}$ Fruit peel color rating: 1 = green, progressively to $5=$ red.

${ }^{y}$ Mean separation within columns by Fisher's protected least significant difference at $P \leq 0.05$. For each strain, every value within a year represents an average of eight replications

Table 4. Effect of 'Fuji' apple strains on fruit firmness at harvest in 6 years.

\begin{tabular}{lccccccc}
\hline & \multicolumn{7}{c}{ Fruit firmness (N) } \\
\cline { 2 - 7 } Strain & 2004 & 2005 & 2006 & 2007 & 2009 & 2010 & Avg 6 years \\
\hline Autumn Rose & $84.4 \mathrm{a}^{\mathrm{z}}$ & $85.3 \mathrm{ab}$ & $79.5 \mathrm{~b}$ & $74.6 \mathrm{a}$ & $77.5 \mathrm{a}$ & $80.4 \mathrm{ab}$ & $80.3 \mathrm{ab}$ \\
Desert Rose & $82.4 \mathrm{a}$ & $83.4 \mathrm{ab}$ & $79.5 \mathrm{~b}$ & $81.4 \mathrm{a}$ & $80.4 \mathrm{a}$ & $75.5 \mathrm{~b}$ & $80.4 \mathrm{ab}$ \\
Myra & $84.4 \mathrm{a}$ & $87.3 \mathrm{a}$ & $83.4 \mathrm{a}$ & $75.5 \mathrm{a}$ & $80.4 \mathrm{a}$ & $82.5 \mathrm{a}$ & $82.3 \mathrm{a}$ \\
September Wonder & $66.7 \mathrm{~b}$ & $70.7 \mathrm{c}$ & $67.7 \mathrm{c}$ & $62.8 \mathrm{~b}$ & $65.7 \mathrm{~b}$ & $68.7 \mathrm{c}$ & $67.1 \mathrm{c}$ \\
Top Export & $82.4 \mathrm{a}$ & $82.4 \mathrm{~b}$ & $78.5 \mathrm{~b}$ & $74.6 \mathrm{a}$ & $77.5 \mathrm{a}$ & $78.5 \mathrm{ab}$ & $79.0 \mathrm{~b}$ \\
\hline
\end{tabular}

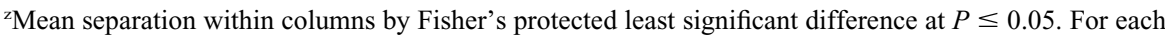
strain, every value within a year represents an average of eight replications.

Table 5. Effect of 'Fuji' apple strains on fruit soluble solids at harvest in 6 years.

\begin{tabular}{|c|c|c|c|c|c|c|c|}
\hline \multirow[b]{2}{*}{ Strain } & \multicolumn{7}{|c|}{ Soluble solids concn (\% Brix) } \\
\hline & 2004 & 2005 & 2006 & 2007 & 2009 & 2010 & Avg 6 year \\
\hline Autumn Rose & $14.1 \mathrm{~b}^{\mathrm{z}}$ & $16.8 \mathrm{a}$ & $15.9 \mathrm{a}$ & $16.0 \mathrm{a}$ & $14.9 \mathrm{~b}$ & $16.2 \mathrm{abc}$ & $15.9 \mathrm{a}$ \\
\hline Desert Rose & $15.7 \mathrm{ab}$ & $17.1 \mathrm{a}$ & $16.6 \mathrm{a}$ & $16.4 \mathrm{a}$ & $15.6 \mathrm{ab}$ & $15.9 \mathrm{bc}$ & $16.3 \mathrm{a}$ \\
\hline Myra & $16.2 \mathrm{a}$ & $17.5 \mathrm{a}$ & $16.7 \mathrm{a}$ & $15.7 \mathrm{a}$ & $15.8 \mathrm{a}$ & $16.7 \mathrm{a}$ & $16.5 \mathrm{a}$ \\
\hline September Wonder & $15.4 \mathrm{ab}$ & $17.4 \mathrm{a}$ & $16.1 \mathrm{a}$ & $15.2 \mathrm{a}$ & $16.0 \mathrm{a}$ & $16.4 \mathrm{ab}$ & $16.1 \mathrm{a}$ \\
\hline Top Export & $16.2 \mathrm{a}$ & $16.8 \mathrm{a}$ & $16.1 \mathrm{a}$ & $15.5 \mathrm{a}$ & $15.5 \mathrm{ab}$ & $15.7 \mathrm{c}$ & $16.0 \mathrm{a}$ \\
\hline
\end{tabular}

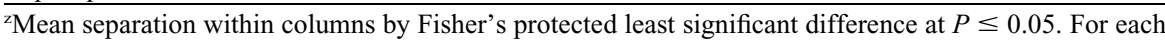
strain, every value within a year represents an average eight replications.

Table 6. Effect of 'Fuji' apple strains on fruit starch degradation pattern at harvest in 6 years.

\begin{tabular}{lccccccc}
\hline & \multicolumn{7}{c}{ Starch degradation pattern $^{\mathrm{z}}$} \\
\cline { 2 - 7 } Strain & 2004 & 2005 & 2006 & 2007 & 2009 & 2010 & Avg 6 years \\
\hline Autumn Rose & $3.7 \mathrm{~b}^{\mathrm{y}}$ & $3.4 \mathrm{~b}$ & $3.3 \mathrm{c}$ & $4.7 \mathrm{bc}$ & $3.5 \mathrm{bc}$ & $3.1 \mathrm{c}$ & $3.7 \mathrm{c}$ \\
Desert Rose & $4.1 \mathrm{~b}$ & $3.8 \mathrm{~b}$ & $3.4 \mathrm{c}$ & $4.1 \mathrm{c}$ & $2.9 \mathrm{~d}$ & $2.8 \mathrm{c}$ & $3.6 \mathrm{~cd}$ \\
Myra & $4.3 \mathrm{~b}$ & $4.0 \mathrm{~b}$ & $4.4 \mathrm{~b}$ & $5.3 \mathrm{ab}$ & $3.8 \mathrm{~b}$ & $3.6 \mathrm{~b}$ & $4.3 \mathrm{~b}$ \\
September Wonder & $5.8 \mathrm{a}$ & $5.3 \mathrm{a}$ & $5.8 \mathrm{a}$ & $5.8 \mathrm{a}$ & $5.5 \mathrm{a}$ & $5.6 \mathrm{a}$ & $5.6 \mathrm{a}$ \\
Top Export & $2.9 \mathrm{c}$ & $3.4 \mathrm{~b}$ & $3.2 \mathrm{c}$ & $4.6 \mathrm{c}$ & $3.1 \mathrm{~cd}$ & $2.8 \mathrm{c}$ & $3.3 \mathrm{~d}$ \\
\hline
\end{tabular}

${ }^{z}$ Starch degradation pattern rating represents starch hydrolysis: $1=$ least, progressively to $6=$ highest.

${ }^{\mathrm{y}}$ Mean separation within columns by Fisher's protected least significant difference at $P \leq 0.05$. For each strain, every value within a year represents an average of eight replications.

Table 7. Effect of 'Fuji' apple strains on fruit watercore and surface cracks at harvest in 6 years.

\begin{tabular}{llllllllc}
\hline & \multicolumn{7}{c}{ Watercore (\%) } & Cracks 6-year \\
\cline { 2 - 8 } Strain & 2004 & 2005 & 2006 & 2007 & 2009 & 2010 & Avg 6 years & avg (\%) \\
\hline Autumn Rose & $16.7 \mathrm{a}^{\mathrm{z}}$ & $75.0 \mathrm{ab}$ & $86.7 \mathrm{ab}$ & $53.3 \mathrm{ab}$ & $62.5 \mathrm{bc}$ & $75.0 \mathrm{a}$ & $53.5 \mathrm{~b}$ & $0.8 \mathrm{bc}$ \\
Desert Rose & $12.5 \mathrm{a}$ & $69.4 \mathrm{ab}$ & $88.9 \mathrm{a}$ & $69.4 \mathrm{ab}$ & $93.3 \mathrm{a}$ & $52.8 \mathrm{a}$ & $62.9 \mathrm{ab}$ & $2.1 \mathrm{ab}$ \\
Myra & $41.7 \mathrm{a}$ & $97.6 \mathrm{a}$ & $85.7 \mathrm{ab}$ & $78.6 \mathrm{a}$ & $97.2 \mathrm{a}$ & $76.2 \mathrm{a}$ & $78.8 \mathrm{a}$ & $1.0 \mathrm{bc}$ \\
S. Wonder & $50.0 \mathrm{a}$ & $66.7 \mathrm{ab}$ & $66.7 \mathrm{~b}$ & $43.3 \mathrm{~b}$ & $58.3 \mathrm{c}$ & $69.4 \mathrm{a}$ & $59.3 \mathrm{ab}$ & $3.5 \mathrm{a}$ \\
Top Export & $16.7 \mathrm{a}$ & $58.3 \mathrm{~b}$ & $83.3 \mathrm{ab}$ & $58.3 \mathrm{ab}$ & $86.1 \mathrm{ab}$ & $52.8 \mathrm{a}$ & $59.3 \mathrm{ab}$ & $0.0 \mathrm{c}$ \\
\hline
\end{tabular}

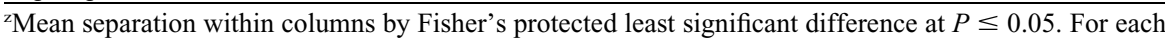
strain, every value within a year represents an average of eight replications.

S. Wonder $=$ September Wonder. 
earlier date than other strains. 'Desert Rose' was a good choice for a late-maturing strain. This strain had excellent color (Table 3), great storability, and shape (data not shown). 'Myra Fuji' was particularly desirable for its attractive pink color that resembles bagged 'Fuji' without the expensive cost of labor associated with bagging. Trees in this strain tended to be slightly more precocious than those of other strains (Table 1). Fruit of 'Myra Fuji' were slightly non-symmetrical (uneven shape) and thus, application of Promalin [benzyladenine, $8 \%(\mathrm{w} / \mathrm{w})+$ gibberellins A4A7, 1.8\% (w/w); Valent BioSciences Corporation, Libertyville, IL] could improve length/diameter ratio (typiness) of fruit in this 'Fuji' and this area deserves further study. If other strains such as 'Desert Rose Fuji' are available in the nurseries, we do not recommend planting 'Autumn Rose Fuji' because it produces fruit with a muddy color under conditions of the Intermountain West region of the United States.

\section{Literature Cited}

Arakawa, O. 1991. Effect of temperature on anthocyanin accumulation in apple fruit as affected by cultivar, stage of fruit ripening, and bagging. J. Hort. Sci. 56:763-768.

Bartram, R.D., W. Bramlage, E.M. Kupferman, K.L. Olsen, M.E. Patterson, and J. Thompson. 1993. Apple maturity program handbook. U.S. Dept. Agri. Res. Serv. Tree Fruit Research Station, Wenatchee, WA.

Baugher, T.A., H.W. Hogmire, and T. Lightner. 1990. Determining apple packout losses and impact of profitability. Appl. Agr. Res. 5:23-26.

Blankenship, S.M. 1987. Night-temperature effects on rate of apple fruit maturation and fruit quality. Sci. Hort. 33:205-212.

Brown, G.S., J. O'Loughlin, and P. Jotic. 1998. A comparison of fruit maturity and quality of four strains of 'Fuji' apples. Acta Hort. 464:491.

Crassweller, R.M. and R.A. Hollender. 1989. Consumer evaluations of 'Delicious' apple strains. Fruit Var. J. 43:139-142.
Curry, E.C. 1997. Temperatures for optimum anthocyanin accumulation in apple tissue. J. Hort. Sci. 72:723-729.

Dickinson, J.P. and A.G. White. 1986. Red color distribution in the skin of 'Gala' apple and some of its sports. N. Z. J. Agr. Res. 29:695698.

Donati, F., A. Gianini, S. Sansavini, W. Guerra, R. Stainer, and S. Pellegrino. 2003. Valutazioni qualitative sensoriali di nuove mele di diversa provenienza. Rivista di Frutticoltura e di Ortofloricoltura 65:65-71.

Fallahi, E., W.M. Colt, B. Fallahi, and I.J. Chun. 2001. Influence of nitrogen and bagging on fruit quality and mineral concentrations of 'BC-2 Fuji' apple. HortTechnology 11:462466.

Fallahi, E., B. Fallahi, M. Amiri, and B. Shafii. 2011. Long-term fruit yield and quality of various Gala apple strain-rootstock combinations under an evapotranspiration-based drip irrigation system. Fruit, Vegetable and Cereal Sci. Biotech. 5:35-39.

Fallahi, E., D.G. Richardson, and M.N. Westwood. 1985. Influence of rootstocks and fertilizers on ethylene in apple fruit during maturation and storage. J. Amer. Soc. Hort. Sci. 110:149-153.

Faragher, J.D. 1993. Temperature regulation of anthocyanin accumulation in apple skin. J. Expt. Bot. 34:1291-1298.

Fisher, D.V. and D.O. Ketchie. 1989. Survey of literature on red strains of 'Delicious'. Washington State University Cooperative Extension Pullman Bulletin EB 1515. p. 23-37.

Greene, D.W. and W.R. Autio. 1993. Comparison of tree growth, fruit characteristics, and fruit quality of five 'Gala' apple strains. Fruit Var. J. 47:103-109.

Iglesias, I. and S. Alegre. 2006. The effect of antihail nets on fruit protection, radiation, temperature, quality and profitability of 'Mondial Gala' apples. J. Appl. Hort. 8:91-100.

Iglesias, I., G. Echeverríab, and M.L. Lopezc. 2012. Fruit color development, anthocyanin content, standard quality, volatile compound emissions, and consumer acceptability of several 'Fuji' apple strains. Sci. Hort. 137:138147.

Iglesias, I., J. Graell, G. Echeverrı'a, and M. Vendrell. 1999. Differences in fruit color development, anthocyanin content, yield and quality of seven 'Delicious' apple strains. Fruit Var. J. 53:133-145.

Ju, Z., Y. Duan, and Z. Ju. 1999. Effects of covering the orchard floor with reflecting film on pigment accumulation and fruit coloration in 'Fuji' apples. Sci. Hort. 82:47-56.

Koike, H. and T. Ono. 2014. Optimum crop load for 'Fuji' apples in Japan. 21 Feb. 2014. $<$ http://www.virtualorchard.net/idfta/cft/1998/ vol31no1/koike/KoikeFuji.html>.

Komatsu, H. 1998. Red Fuji in Japan-choosing the best strain for young business strategy. Inter. Dwarf Tree Fruit Assoc. 31:44-45.

Lacey, C.N. and A.L. Campbell. 1987. Selection, stability and propagation of mutant apples, $\mathrm{p}$. 349-362. In: Abbott, A.J. and R.K. Atkin (eds.). Improving vegetatively propagated crops. Academic Press, New York, NY.

MacFie, H. 1995. Consumer preference and sensory studies on southern and northern hemisphere dessert apples. European Apple 3:12-13.

Marini, R.P., R.P. Moran, C. Hampson, M. Kushad, R.L. Perry, and T.L. Robinso. 2008. Effect of dwarf apple rootstocks on average 'Gala' fruit weight at six locations over three seasons. J. Amer. Pomol. Soc. 62:129-136.

Salveit, M.E. 1983. Relationship between ethylene production and taste panel preference of 'Starkrimson Red Delicious' apples. Can. J. Plant Sci. 63:303-306.

Sansavini, S., F. Donati, F. Costa, and S. Tartarini. 2005. Il miglioramento genetico delmelo in Europa: Tipologie di frutto, obiettivi e nuove varieta. Frutticoltura: Speciale melo 11:14-27.

Saure, M.C. 1990. External control of anthocyanin formation in apple. Sci. Hort. 42:181-218.

Veberic, R., P. Zadravec, and F. Stampar. 2007. Fruit quality of 'Fuji' apple (Malus domestica Borkh.) strains. J. Sci. Food Agr. 87:593599.

Washington State University Tree Fruit Research and Extension Center. 2014. 17 Jan. 2014. $<$ http://www.tfrec.wsu.edu $>$.

Westwood, M.N. 1993. Temperate-zone pomology: Physiology and culture. 3rd Ed. Timber Press, Portland, OR.

Williams, K.M. 1993. Use of evaporative cooling for enhancing apple fruit quality. Good Fruit Grower 8:23-27. 